\title{
Clinical lessons from GENDEP for the treatment of depression
}

\author{
Katherine J Aitchison
}

From $1^{\text {st }}$ International Congress on Neurobiology and Clinical Psychopharmacology and European

Psychiatric Association Conference on Treatment Guidance

Thessaloniki, Greece. 19-22 November 2009

In GENDEP, a European multicentre pharmacogenomic study http://gendep.iop.kcl.ac.uk/results.php, subjects with major depression were treated with escitalopram (ESC) or nortriptyline (NOR), in a part-randomised potential crossover design, and prospectively rated for response and ADRs with measures including the MADRS, HDRS, BDI, UKU, and ASEC (a self-report measure developed for GENDEP, Uher et al, in press). Factor analysis and Item Response Theory applied to the three measures of depression employed in the study generated three symptom dimensions. Mixed linear regression models showed no difference between ESC and NOR on the three original scales, but symptom dimensions revealed drug-specific advantages: observed mood and cognitive symptoms improved more with ESC than with NOR; neurovegetative symptoms improved more with NOR than with ESC. CYP2C19 genotypic category significantly predicted steady-state (week 8) ESC concentration. Analysis of baseline weight as a predictor revealed that lower BMI predicted better response to NOR. There was good agreement between the UKU and the ASEC, and urinary symptoms, dry mouth, blurred vision, and orthostatic hypotension predicted discontinuation of either drug.

Published: 22 April 2010

doi:10.1186/1744-859X-9-S1-S6

Cite this article as: Aitchison: Clinical lessons from GENDEP for the

treatment of depression. Annals of General Psychiatry 2010 9(Suppl 1):S6.

MRC SGDP Centre, Institute of Psychiatry at King's College London and Honorary Consultant Psychiatrist, South London \& Maudsley NHS Foundation Trust, UK

(C) 2009 Aitchison; licensee BioMed Central Ltd.
Submit your next manuscript to BioMed Central and take full advantage of:

- Convenient online submission

- Thorough peer review

- No space constraints or color figure charges

- Immediate publication on acceptance

- Inclusion in PubMed, CAS, Scopus and Google Scholar

- Research which is freely available for redistribution

Submit your manuscript at www.biomedcentral.com/submit
C Biomed Central 